\title{
Role of Interventional Radiology in the Management of Peripheral Vascular Malformations: A Tertiary Care Center Experience
}

Misbah Tahir Dr ${ }^{1}$, Muhammad Anees Mumtaz ${ }^{2}$, Anum Sultan ${ }^{3}$, Jawaid Iqbal Dr. ${ }^{1}$, Raza Sayani ${ }^{4}$

1. Radiology, Liaquat National Hospital and Medical College, Karachi, PAK 2. Medical College, Liaquat National Hospital and Medical College 3. Radiology, Dr. Ziauddin Hospital, Karachi, PAK 4. Department of Radiology, The Aga Khan University, Karachi, PAK

$\square$ Corresponding author: Raza Sayani, sayani_raza@yahoo.com

Disclosures can be found in Additional Information at the end of the article

\section{Abstract}

Peripheral vascular malformations (PVMs) represent a wide spectrum of vascular abnormalities occurring due to anomalous connections between arteries, veins, capillaries, and lymphatic channels at the microscopic level, in different combinations. They are rare and challenging to treat. Different operators may have different approaches based on their experience and expertise. Sclerotherapy either alone or in combination with embolization has been used as an independent method for the treatment of PVMs.

\section{Purpose}

The aim of this study is to assess the safety and efficacy of sclerotherapy and embolization, with or without surgery, for the treatment of peripheral vascular malformations, based on our approach.

\section{Materials and methods}

A retrospective review of all patients with PVMs treated in our interventional radiology department from 2011 to 2017 was carried out. Medical records, imaging, and follow-up notes were reviewed to evaluate the response to treatment and post-procedure complications.

\section{Results}

Received 03/07/2018 Review began 03/09/2018 Review ended 03/14/2018 Published 03/16/2018

\section{(c) Copyright 2018}

Tahir et al. This is an open access article distributed under the terms of the Creative Commons Attribution License CC-BY 3.0., which permits unrestricted use, distribution, and reproduction in any medium, provided the original author and source are credited.
Thirty-four sessions were performed in 15 patients (eight male, seven female) with PVMs. Lowflow lesions were identified in 10, intermediate flow in one, and high flow in four patients. Sodium tetradecyl sulfate (STS) was used as the sclerotherapeutic agent in 10 (66.67\%), glue with lipoidal in three (20.0\%), and bleomycin in one patient (6.67\%). Coils with PVA and a covered stent were used in one and a combination of coil, PVA, and gel foam was used in one patient. A marked response was seen in 11 and a partial response in four patients. One patient developed foot gangrene. Stent thrombosis was noted in one patient with no clinical consequences. Recurrence was seen in two patients, who were lost to follow up.

\section{Conclusion}

PVMs are complex lesions. Sclerotherapy with or without embolization is a safe and effective treatment modality, with clinical response approaching $100 \%$.

How to cite this article

Tahir M, Mumtaz M, Sultan A, et al. (March 16, 2018) Role of Interventional Radiology in the Management of Peripheral Vascular Malformations: A Tertiary Care Center Experience. Cureus 10(3): e2335. DOI 10.7759 /cureus. 2335 
Categories: Dermatology, Radiology, General Surgery

Keywords: sclerotherapy, vascular malformation, sodium tetradecyl sulphate, bleomycin, ethanol, ethanolamine oleate, glue, covered stents, coils, polyvinyl alcohol particles

\section{Introduction}

Peripheral vascular malformations (PVMs) represent a wide spectrum of vascular abnormalities occurring due to anomalous connections between arteries, veins, capillaries, and lymphatic channels at the microscopic level, in different combinations [1]. These lesions are characterized as low-, intermediate-, and high-flow lesions depending upon the flow velocity. Symptoms such as pain, swelling, functional disabilities, and cosmetic deformity can lead to significant morbidity.

Sclerotherapy either alone or in combination with embolization has been used as an independent method for the treatment of PVMs. It can also be used as an adjunct to surgery [23]. Various agents are used in sclerotherapy and the embolization of PVMs, including sodium tetradecyl sulfate (STS), bleomycin, ethanol, ethanolamine oleate, glue, covered stents, coils, polyvinyl alcohol particles (PVA), and gel foam. The selection of sclerotherapeutic and embolizing agents vary depending on the location and characteristics of vascular malformations and radiologist preference. As PVMs are rare in occurrence, challenging to treat, and there is significant variation in the choice of sclerotherapeutic and embolizing agents among different operators depending on their personal preference and experience, we wanted to see the safety and efficacy of our initial experience in treating PVMs.

\section{Materials And Methods}

In this study, we carried out a retrospective review of all peripheral vascular malformations (PVMs) treated in our vascular interventional radiology (VIR) department from 2011 to 2017. Informed consent was obtained from all patients. The diagnosis of PVMs was made on the basis of physical examinations and imaging. Imaging modalities included ultrasound (U/S) and magnetic resonance imaging (MRI) in all patients. In high- and intermediate-flow lesions, angiography was also performed. U/S imaging was done on Toshiba Xario 100 (Canon Medical Systems Corporation, Tochigi Prefecture, Japan) using $5 \mathrm{MHz}$ and $7.5 \mathrm{MHz}$ high-frequency probes with color Doppler. Magnetic resonance imaging (MRI) was done on Toshiba Excelart Vantage (ATLAS) 1.5 Tesla (Canon Medical Systems Corporation, Tochigi Prefecture, Japan). The MRI protocol included T1-, T2-weighted images with and without fat saturation and postcontrast T1-weighted images with fat saturation in the axial, coronal, and sagittal planes.

Lesions were characterized as high, intermediate, and low flow depending on their flow pattern and velocities. Lesions showing only monophasic venous flow were labeled as low flow and those with a predominant arterial flow pattern were labeled as high flow. PVMs with predominant venous low but also having arterial flow were taken as intermediate flow. Sclerotherapy and embolization were performed under real-time U/S and fluoroscopic guidance using STS (3\% sodium tetradecyl sulphate, Setrol, Samrath Life Sciences, Mumbai, India), glue (Glubran, GEM S.R.L, Viareggio, Italy) with lipoidol (lipoidol ultra-fluid $480 \mathrm{mg} / \mathrm{ml}$, Guerbet, Istanbul), bleomycin (Bleomycin 15mg, Fresenius Kabi, USA), covered stent (wall graft, Boston Scientific, USA), gelfoam (Equispon, Eguimedical BV, The Netherlands), coils (2D Helical-35, Boston Scientific, Cork, Ireland), and PVA particles (Contour, Boston Scientific, USA). Sclerotherapeutic and embolizing agents were selected according to the location and characteristics of PVMs.

STS was used for low and intermediate-flow lesions and high-flow lesions were embolized using a covered stent, coils, PVA, gel foam, glue, and bleomycin in various combinations, as 


\section{Cureus}

shown in Table 1.

\begin{tabular}{|c|c|c|c|c|c|c|c|c|c|c|c|}
\hline Patient & $\begin{array}{l}\text { Age } \\
\text { (years) }\end{array}$ & Gender & $\begin{array}{l}\text { Location of } \\
\text { PVMs }\end{array}$ & Presenting symptoms & Flow & $\begin{array}{l}\text { No. of } \\
\text { sessions }\end{array}$ & $\begin{array}{l}\text { Sclerosing } \\
\text { agent }\end{array}$ & $\begin{array}{l}\text { Clinical } \\
\text { response }\end{array}$ & Outcome & Complications & $\begin{array}{l}\text { Duration } \\
\text { of } \\
\text { follow- } \\
\text { up }\end{array}$ \\
\hline 1. & 10 & Male & $\begin{array}{l}\text { Bilateral } \\
\text { parapharyngeal } \\
\text { spaces }\end{array}$ & $\begin{array}{l}\text { Progressive dyspnea and dysphagia. } \\
\text { Dyspnea aggravated during sleep, } \\
\text { resulting in an inability to go into deep } \\
\text { sleep. }\end{array}$ & Low & 3 & STS & $\begin{array}{l}\text { Resolution of } \\
\text { dyspnea }\end{array}$ & $\begin{array}{l}\text { Marked } \\
\text { response }\end{array}$ & None & $\begin{array}{l}19 \\
\text { months }\end{array}$ \\
\hline 2. & 16 & Female & $\begin{array}{l}\text { Planter and } \\
\text { dorsal aspect of } \\
\text { right foot }\end{array}$ & $\begin{array}{l}\mathrm{K} / \mathrm{c} \text { right foot vascular malformation, } \\
\text { pain in right foot }\end{array}$ & Low & 1 & STS & $\begin{array}{l}\text { Resolution of } \\
\text { pain }\end{array}$ & $\begin{array}{l}\text { Marked } \\
\text { response }\end{array}$ & $\begin{array}{l}\text { Distal foot } \\
\text { gangrene }\end{array}$ & $\begin{array}{l}16 \\
\text { months }\end{array}$ \\
\hline 3. & 37 & Female & $\begin{array}{l}\text { Right } \\
\text { parapharyngeal } \\
\text { space extending } \\
\text { into larynx }\end{array}$ & $\begin{array}{l}\text { Painless swelling in the neck on } \\
\text { the right side for last } 2 \mathrm{yrs} \text { that is } \\
\text { progressively increasing in size }\end{array}$ & Low & 2 & STS & $\begin{array}{l}50 \% \\
\text { reduction in } \\
\text { swelling }\end{array}$ & $\begin{array}{l}\text { Partial } \\
\text { response }\end{array}$ & None & $\begin{array}{l}16 \\
\text { months }\end{array}$ \\
\hline 4. & 23 & Female & $\begin{array}{l}\text { Posterior aspect } \\
\text { of left calf }\end{array}$ & $\begin{array}{l}\text { Pain in the left leg for } 10 \mathrm{yrs} \text { that was } \\
\text { increasing in severity for the last } 2 \mathrm{yrs}\end{array}$ & Low & 1 & STS & $\begin{array}{l}\text { Resolution of } \\
\text { pain }\end{array}$ & $\begin{array}{l}\text { Marked } \\
\text { response }\end{array}$ & None & $\begin{array}{l}14 \\
\text { months }\end{array}$ \\
\hline 5. & 31 & Male & $\begin{array}{l}\text { Lateral aspect of } \\
\text { right elbow }\end{array}$ & Severe pain in right arm & Low & 3 & STS & $\begin{array}{l}\text { Resolution of } \\
\text { pain. }\end{array}$ & $\begin{array}{l}\text { Marked } \\
\text { response }\end{array}$ & None & $4 \mathrm{yrs}$ \\
\hline 6. & 35 & Male & Left eyelid & $\begin{array}{l}\text { Ptosis of left eyelid, difficulty in } \\
\text { opening the eye, no visual } \\
\text { impairment }\end{array}$ & High & 1 & Bleomycin & $\begin{array}{l}\text { Significant } \\
\text { resolution. He } \\
\text { was able to } \\
\text { open his eye. }\end{array}$ & $\begin{array}{l}\text { Partial } \\
\text { response }\end{array}$ & None & $\begin{array}{l}\text { Lost to } \\
\text { F/U. }\end{array}$ \\
\hline 7. & 32 & Male & Right ankle & Pain in right ankle extending into calf & Low & 7 & $\begin{array}{l}\text { Glue with } \\
\text { lipiodol }\end{array}$ & $\begin{array}{l}50 \% \\
\text { reduction in } \\
\text { size on post- } \\
\text { procedure } \\
\text { MRI }\end{array}$ & $\begin{array}{l}\text { Partial } \\
\text { response }\end{array}$ & None & $5 \mathrm{yrs}$ \\
\hline 8. & 18 & Female & Right lower limb & $\begin{array}{l}\text { Multiple lesions in right lower limb, } \\
\text { pain in right lower limb }\end{array}$ & Low & 2 & STS & $\begin{array}{l}\text { Resolution of } \\
\text { pain }\end{array}$ & $\begin{array}{l}\text { Marked initial } \\
\text { response, } \\
\text { recurrence on } \\
\text { 2-yr F/U }\end{array}$ & None & $3 \mathrm{yrs}$ \\
\hline 9. & 18 & Female & Left arm & Left arm pain and swelling & High & 2 & $\begin{array}{l}\text { Glue with } \\
\text { lipiodol, } \\
\text { wall-graft } \\
\text { stent. }\end{array}$ & $\begin{array}{l}\text { Resolution of } \\
\text { pain and } \\
\text { swelling }\end{array}$ & $\begin{array}{l}\text { Marked } \\
\text { response }\end{array}$ & None & $4 \mathrm{yrs}$ \\
\hline 10. & 22 & Female & Right distal thigh & $\begin{array}{l}\text { Pain and swelling in right distal thigh } \\
\text { since childhood increasing for } 2-3 \text { yrs }\end{array}$ & Low & 3 & STS & $\begin{array}{l}\text { Resolution of } \\
\text { pain }\end{array}$ & $\begin{array}{l}\text { response, } \\
\text { recurrence on } \\
\text { 3yr F/U }\end{array}$ & None & $4 \mathrm{yrs}$ \\
\hline & & & & & & & Coils with & Cessation of & Marked & & \\
\hline
\end{tabular}




\section{Cureus}

\begin{tabular}{|c|c|c|c|c|c|c|c|c|c|c|c|}
\hline 11. & 20 & Male & Face & Bleeding from gums & High & 1 & $\begin{array}{l}\text { PVA and } \\
\text { gel foam }\end{array}$ & bleeding & response & None & 4 yrs \\
\hline 12. & 17 & Male & Right arm & $\begin{array}{l}\text { Pain on compression, swelling } \\
\text { increasing in size }\end{array}$ & Low & 2 & STS & $\begin{array}{l}\text { Resolution of } \\
\text { pain and } \\
\text { swelling }\end{array}$ & $\begin{array}{l}\text { Marked } \\
\text { response }\end{array}$ & None & 3 yrs \\
\hline 13. & 18 & Female & Face & $\begin{array}{l}\text { Extensive vascular malformation on } \\
\text { face }\end{array}$ & High & 2 & $\begin{array}{l}\text { Coils with } \\
\text { PVA }\end{array}$ & $\begin{array}{l}\text { Complete } \\
\text { resolution }\end{array}$ & $\begin{array}{l}\text { Marked } \\
\text { response }\end{array}$ & None & $4 \mathrm{yrs}$ \\
\hline 14. & 22 & Male & Left forearm & $\begin{array}{l}\text { Pain and swelling increasing in size } \\
\text { for last } 3 \text { months }\end{array}$ & Intermediate & 1 & $\begin{array}{l}\text { STS, Glue } \\
\text { with lipiodol }\end{array}$ & $\begin{array}{l}\text { Resolution of } \\
\text { pain and } \\
\text { swelling }\end{array}$ & $\begin{array}{l}\text { Marked } \\
\text { response }\end{array}$ & None & $\begin{array}{l}13 \\
\text { months }\end{array}$ \\
\hline 15 & 22 & Male & Neck & $\begin{array}{l}\text { Diffuse neck swelling with difficulty in } \\
\text { breathing and swallowing }\end{array}$ & low & 2 & STS & $\begin{array}{l}60 \% \text { to } 70 \% \\
\text { resolution of } \\
\text { swelling and } \\
\text { symptoms }\end{array}$ & $\begin{array}{l}\text { Marked } \\
\text { response }\end{array}$ & None & 5 months \\
\hline
\end{tabular}

TABLE 1: Patients' information according to region involved, presenting symptoms, flow characteristics, number of sessions, agents used, response, and follow-up.

After localizing the lesion under U/S, cannulation with a needle (20G, 22G, 25G BD spinal needle, Becton Dickinson SA, Spain) was done and contrast (Iomeprol, Braccos PA, Milano, Italy) was injected to delineate the lesion on fluoroscopy. A percutaneous injection of sclerotherapeutic and embolizing agents was done using $\mathrm{U} / \mathrm{S}$ and fluoroscopic guidance. The outflow veins were occluded or compressed using a tourniquet during the injection, wherever possible. STS foam was created with STS mixed with air and contrast, each in equal amounts. People have mixed STS with lipiodol but because of the financial constraints of many patients in Pakistan, we are using non-ionic contrast instead of lipiodol. Glue was usually injected in combination with lipiodol in a 1:1 ratio. The amount of glue and lipiodol varied according to the lesion size and response. The injection was stopped when thrombosis of vascular channels was seen on U/S and a loss of flow was identified on angiography. However, angiography was done only in selected cases in intermediate- and high-flow lesions.

Technical success is defined as the optimal injection of sclerosant or the exclusion of lesion by embolization as demonstrated by angiography or $\mathrm{U} / \mathrm{S}$. Clinical success is assessed by a reduction in pain and an improvement in swelling and function. Clinical response is categorized as marked response, partial response, and no response. Patients showing complete resolution of symptoms were labeled as having marked response, those showing a reduction in symptoms as partial response, and as no response when no change in symptoms was noted. Clinical outcomes were determined by reviewing all the pre- and post-procedure imaging and follow-up notes in the interventional radiology clinic. MRI was not routinely done in the follow-up of all patients. Follow-up of all patients included clinical evaluation, physical examination, and grayscale and color Doppler U/S.

\section{Results}

Thirty-four sessions were performed in 15 patients (eight male, seven female) with PVMs. The mean age of patients was 22.7 years (range 10-37 years). Nine patients had pain (60.0\%), six had a swelling (40.0\%), one had ptosis (6.67\%), two had dyspnea affecting sleep significantly (13.34\%), and one patient presented with life-threatening oral hemorrhage (6.67\%). One 


\section{Cureus}

patient with low-flow vascular malformation in a lower limb had prior surgery with no significant response. The average follow-up duration was 2.71 years (0.4-5 years). The distribution of vascular malformation according to flow characteristics and region of involvement is shown in Table 2.

\begin{tabular}{|c|c|c|c|c|}
\hline \multirow{2}{*}{ Region involved } & \multicolumn{3}{|c|}{ PVMs flow characteristics } & \multirow{2}{*}{ Total } \\
\hline & High flow & Intermediate flow & Low flow & \\
\hline Upper limb & 1 & 1 & 2 & 4 \\
\hline Lower limb & 0 & 0 & 5 & 5 \\
\hline Head and neck & 3 & 0 & 3 & 6 \\
\hline Total & 4 & 1 & 10 & 15 \\
\hline
\end{tabular}

\section{TABLE 2: Distribution of vascular malformations according to flow characteristics and region of involvement}

STS alone was used as the sclerotherapeutic agent in nine patients. Glue with lipiodol was used in three patients. Out of these, one had covered stent placement and another had STS injection. Bleomycin was used in one patient. Coils along with PVA particles were used in one patient and a combination of coils, PVA, and gel foam was used in one patient with a high-flow vascular malformation. A 100\% technical success rate was achieved. Clinical success was $100 \%$. A marked clinical response was seen in 11 out of 15 patients (73.34\%) with a resolution of symptoms. Four out of 15 (26.67\%) patients showed partial response and no patients were noted in the no response category. One patient developed complication in the form of gangrene in the toes and the second to fifth toes were amputated. Stent thrombosis was noted in one patient without any clinical consequences or functional restriction. Therefore, we did not go for further intervention for the restoration of stent patency. A recurrence was seen in three patients who were lost to follow-up and visited us two and three years later.

\section{Discussion}

PVMs are rare and challenging lesions to treat with an estimated prevalence of $1.5 \%$ in the population [4]. A multidisciplinary approach, including an interventional radiologist, surgeon, dermatologist, hematologist, pathologist, and oncologist, is critical in the diagnosis and management of PVMs. Many times, surgical excision because of the proximity of vital structures is not possible for the treatment of PVMs. Therefore, it is of immense importance that the interventional radiologist is aware of the available treatment techniques and is skilled in their implementation, keeping in view the associated benefits, complications, and outcomes.

In our study, we have performed sclerotherapy in two patients having vascular malformations in the foot. One patient had a vascular malformation in both the planter and dorsal aspects of the foot. Surgery was attempted but complete excision was not achieved. At three different sites, STS foam admixed with glue and air was injected and a compression bandage was applied. The patient developed distal foot gangrene and all toes were amputated. There was a complete response with a resolution of pain and lesion on follow-up. In our opinion, this complication developed due to the tight compression bandage applied after the procedure and the inability of duty doctors to appreciate an ischemic event in a timely manner. Moreover, this 


\section{Cureus}

patient also had a previous surgery of the foot that led to compromised vascular supply and may have contributed to the development of gangrene. Therefore, care should be taken in applying a compression bandage after sclerotherapy so that a venous outflow obstruction resulting in the swelling of the limb or vascular compromise should not occur. Close patient observation is necessary following the sclerotherapy of lesions involving limbs distally. Weiss et al. reported that $30 \mathrm{mmHg}$ support stockings worn for three weeks after sclerotherapy is not only effective immediately after injection but also yield better results in the long term [5]. The two other patients had a vascular malformation in the lower limb, one in the foot and the other in the thigh. Sclerotherapy was done using STS in both patients. There was a complete clinical response with no complication; however, they were lost to follow-up and later presented with a recurrence of the disease and symptoms. This signifies the fact that long-term follow-up is mandatory in PVMs for achieving marked clinical success. Patients who are lost to follow-up may present with a recurrence of symptoms.

An 18-year-old female presented with pain in the left upper limb. Imaging revealed multiple, tiny outpouchings arising from the brachial artery, which were excluded by placing a covered stent (Figure 1).

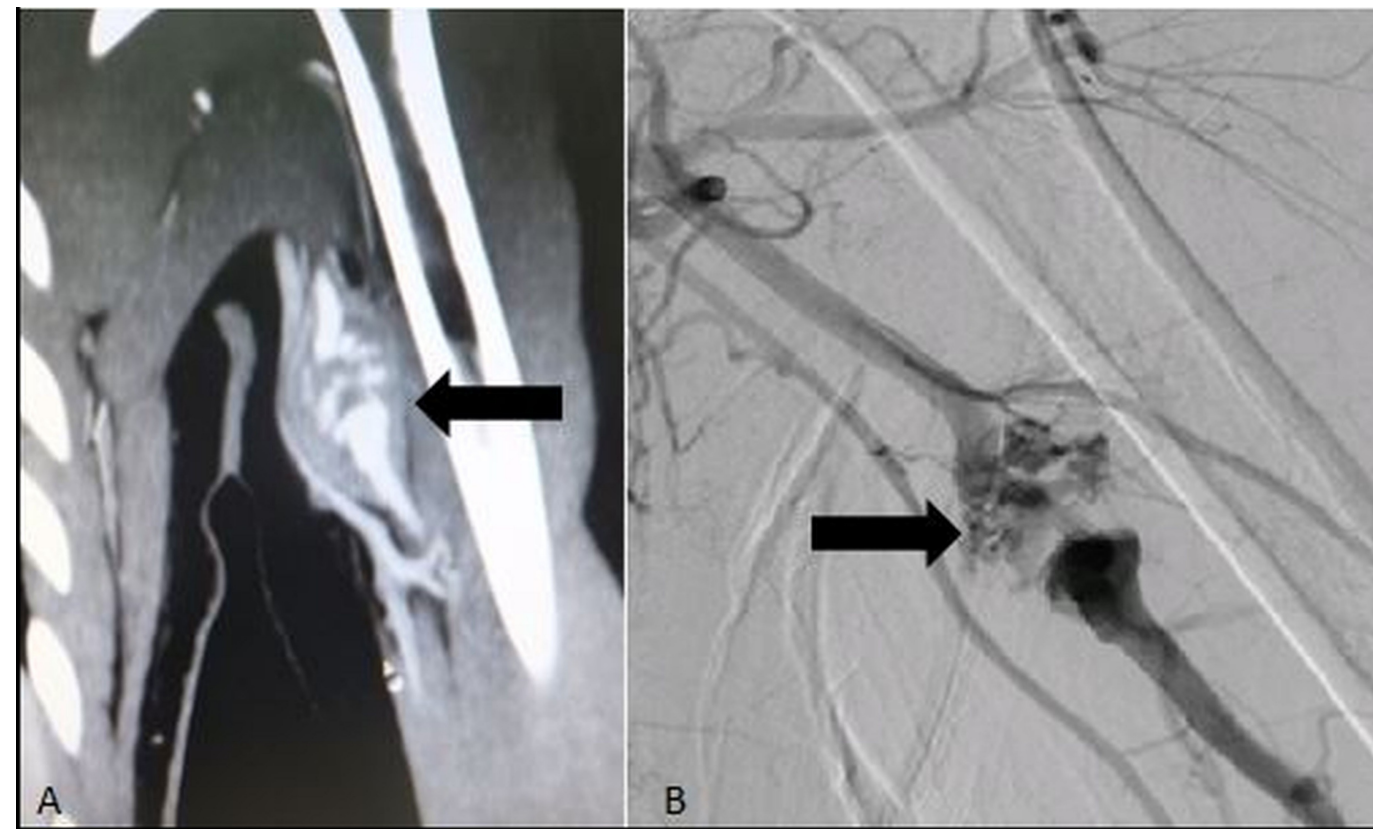

FIGURE 1: CT scan with contrast (A) and digital subtraction angiogram (B) of an 18-year-old patient showing multiple tiny outpouchings (Arrows) arising from the brachial artery

Post-stenting angiogram revealed a few vascular channels filling in the venous phase (Figure 2). 


\section{Cureus}

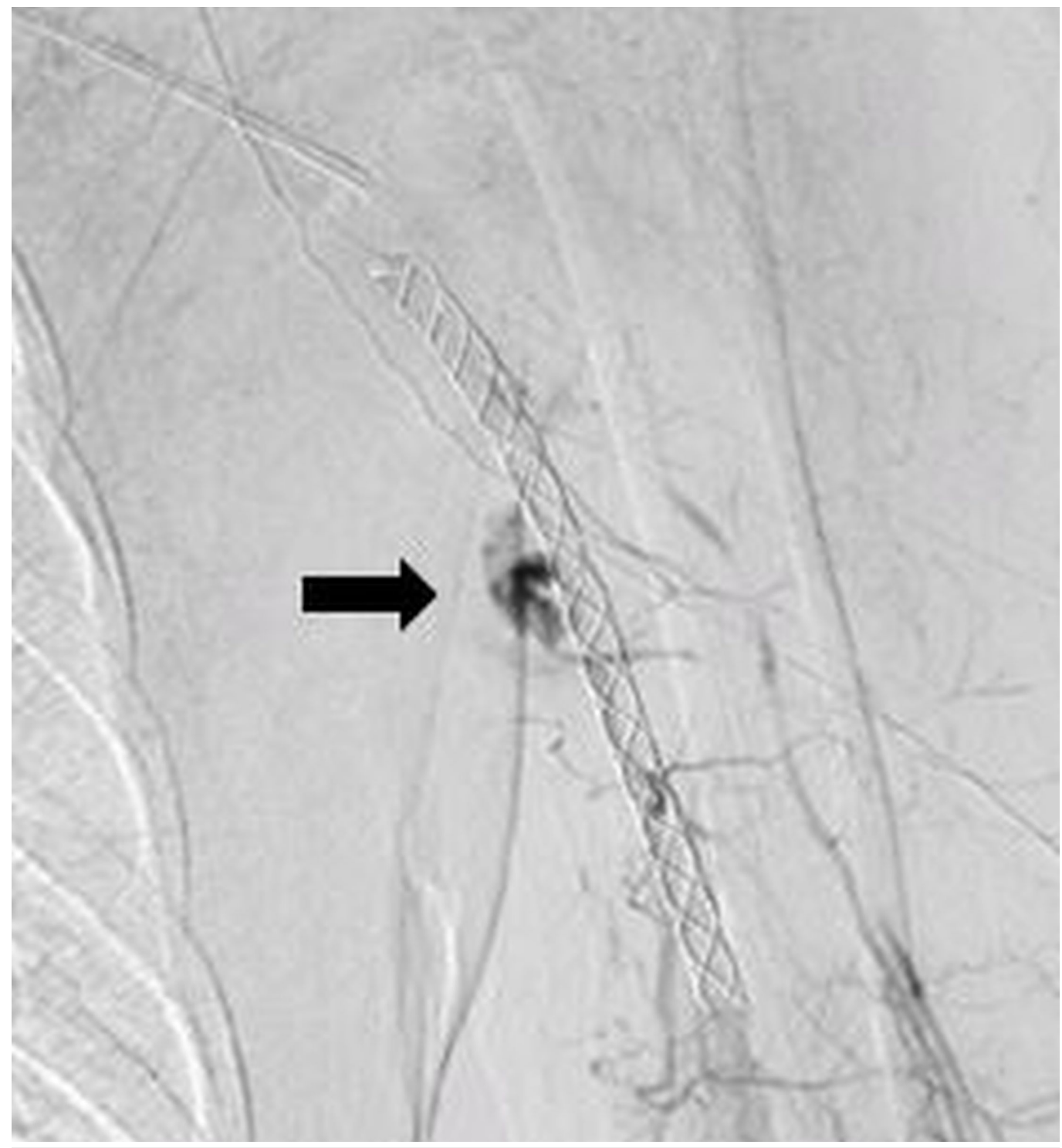

FIGURE 2: Post-stenting angiogram showing a few vascular channels (Arrow) filling in the venous phase

These were embolized with a percutaneous injection of glue, resulting in the complete exclusion of the lesion (Figure 3). 


\section{Cureus}

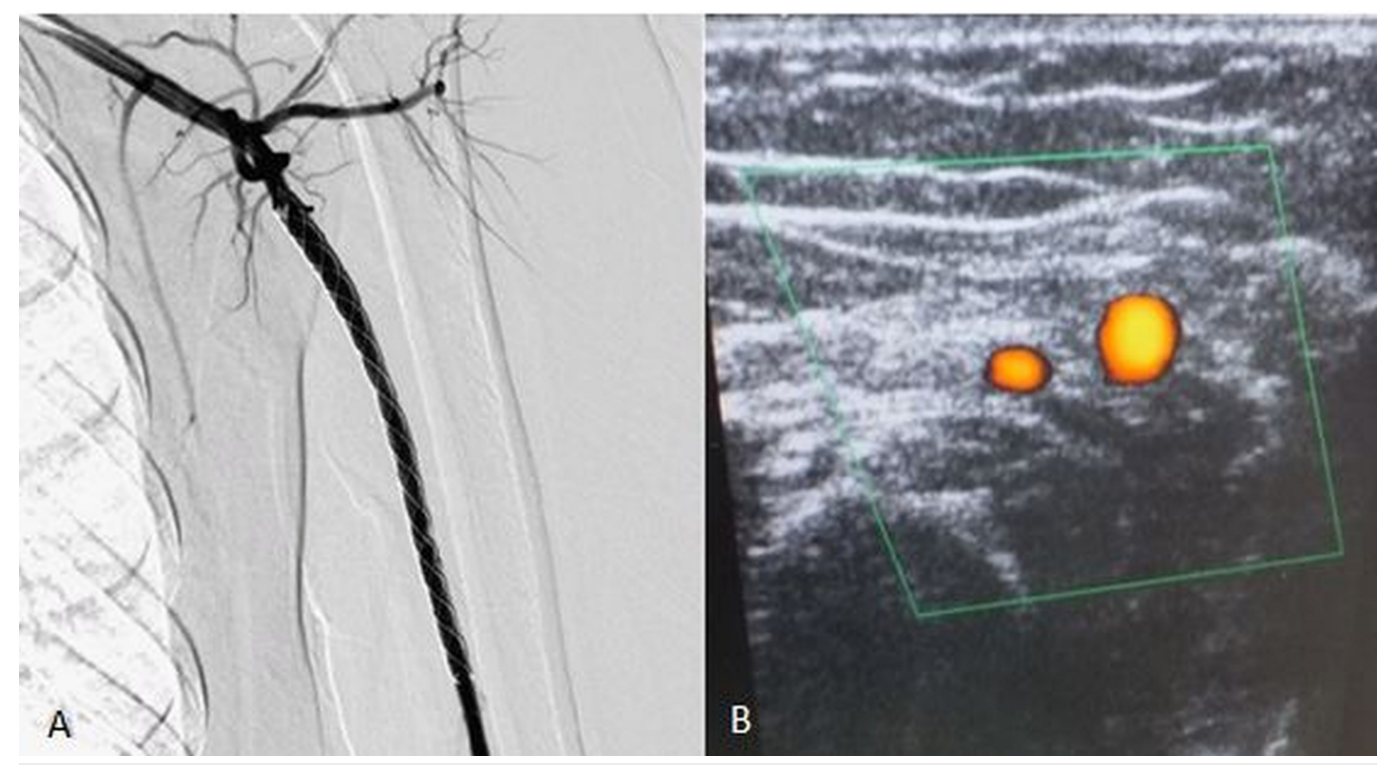

\section{FIGURE 3: Post-procedure angiogram (A) and Doppler ultrasound $(B)$ showing the complete exclusion of the lesion}

At the three months follow-up, the occlusion of the stent was noted with the development of collaterals from the profunda brachii artery, re-forming the brachial artery with a good distal flow. There was no pain or limitation of movement, so no further intervention was done and the patient has been asymptomatic for the last three years. We did not include it as a complication. Out of 15 patients, nine have vascular malformations in the limbs and only one patient developed complications in the form of gangrene. Ali S et al. reported a $20 \%$ complication rate in the treatment of venous malformations treated with percutaneous sclerotherapy [6]. Our experience shows a low risk of complication (6.67\%) in patients with PVMs. It is significantly lower as compared to the previous studies [7-9].

Castren E et al. [10] published a series of 75 patients who underwent sclerotherapy for vascular malformations (VM) in the region of the head and neck with a $17.3 \%$ complication rate. In our study, we treated six patients with vascular malformations in the region of the head and neck with a significant improvement in pain, swelling, and function without any complication. One patient had extensive vascular malformation involving the carotid, pharyngeal, and parapharyngeal spaces, causing a significant compression of the airway, resulting in an inability to sleep. To avoid the compression of the airway from inflammation and edema, a tracheostomy was done before the sclerotherapy. His follow-up MRI after two sessions of sclerotherapy revealed intermediate and low signals appearing in a previously noted homogenously T2W hyperintense lesion. A concomitant laryngoscope examination revealed a decrease in the size and pressure effect of VM over the airway. A marked clinical response was noted in this patient with significant improvement in his symptoms. In another patient, a high-flow vascular malformation was noted in the upper eyelid, causing marked ptosis of the eyelid. Sclerotherapy with bleomycin was performed and partial response was noted after the procedure. This patient didn't turn up for follow-up.

A 22-year-old male presented with a huge neck swelling, which caused episodic dyspnea. A computed tomography (CT) scan revealed significant pressure over the airway. Two sessions of sclerotherapy were performed after endotracheal intubation. A significant reduction in swelling with a resolution of dyspnea was noted in the five-month follow-up (Figure 4). 


\section{Cureus}

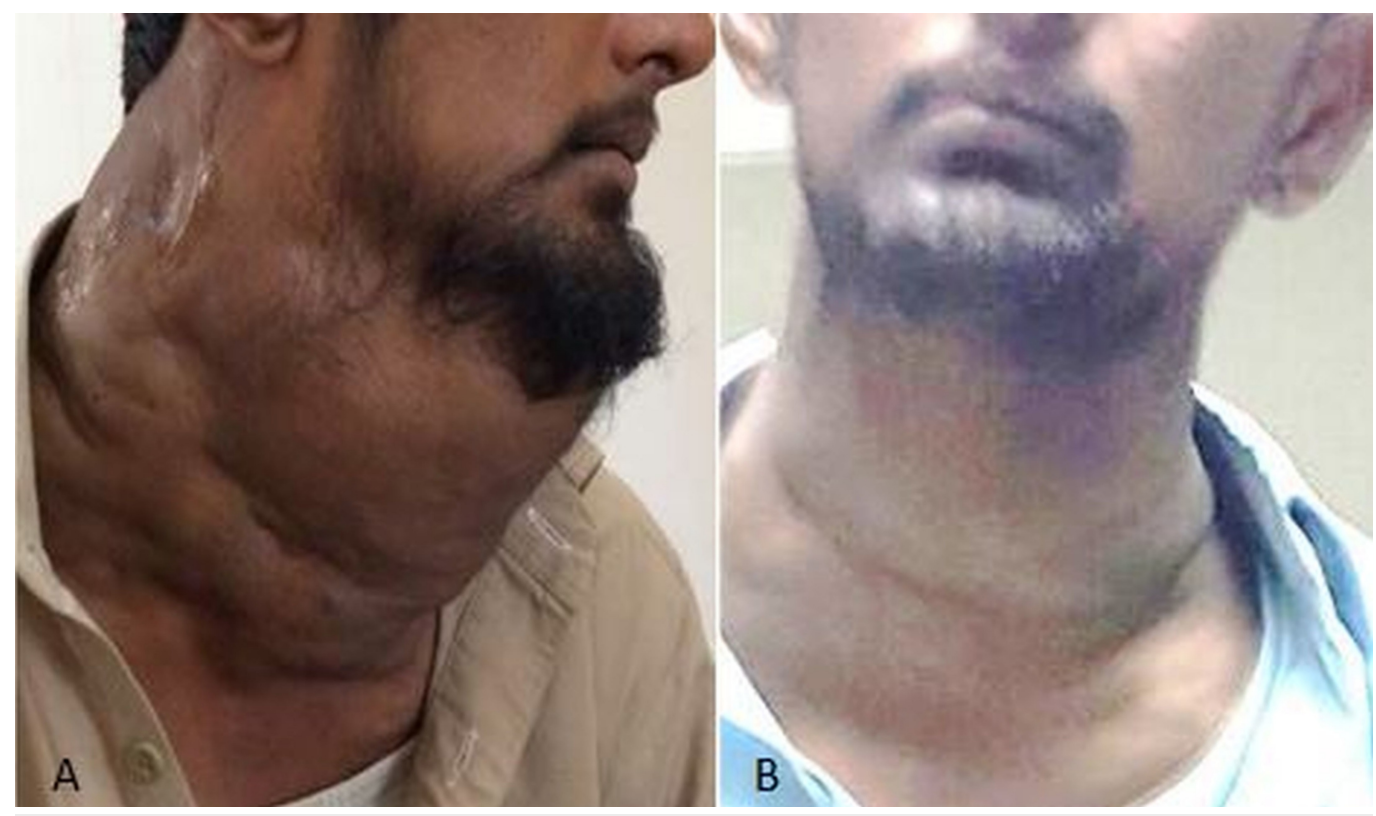

FIGURE 4: A. Patient presented with a diffuse neck swelling. B. Marked reduction noted in the neck swelling after sclerotherapy with STS

STS: sodium tetradecyl sulfate

None of our patients with a vascular malformation in the head and neck developed complications after the procedure.

In the literature, there is a difference in the choice of sclerotherapeutic agents among different authors. We have used STS as the sclerotherapeutic agent in most of our procedures, as it is one of the most-effective and safest agents used for sclerotherapy, with a success rate comparable to ethanol [11]. However, it can cause various adverse reactions, such as sloughing and necrosis of tissues, skin discoloration, and allergic reactions. The incidence of allergic reactions after STS injections ranges from $0.15 \%$ to $0.30 \%$. In our study, only one patient developed an allergic response to the test dose of STS. This patient had seven sessions of sclerotherapy. Bleomycin was also given but there was no clinical response. In this patient, we used glue admixed with lipiodol for sclerotherapy. He showed a marked clinical response. Allergic and anaphylactic responses were also reported with the use of STS in previous studies. In our study, wherever possible, we used glue with lipiodol in high- and intermediate-flow lesions and STS in low-flow lesions, and we found it a very effective combination.

The majority of patients with PVMs may require multiple sessions. In our study, only five out of 15 patients (33.3\%) had a single session. Six out of 15 patients (40\%) had two sessions. Three out of 15 patients (20\%) had three sessions and one patient had seven sessions.

The results of our study demonstrated a marked response in $73.34 \%$ of patients and a partial response in $26.67 \%$ with a $0 \%$ failure rate.Two patients with high-flow malformation underwent surgery after sclerotherapy with a complete excision of the lesion. With the mean follow-up of 2.71 years, we conclude that sclerotherapy with or without embolization is a safe and effective treatment modality, with most patients experiencing symptom relief. STS is a safe and effective treatment modality; however, it needs multiple sessions and long-term follow-up. Special attention, with effective monitoring, should be done for distal extremity and head and neck 
lesions.

The limitations of our study are that it is a retrospective study with a small sample size.

\section{Conclusions}

PVMs are complex lesions. Sclerotherapy, with or without embolization, is a safe and effective treatment modality with clinical success approaching 100\%. Many patients will need multiple sessions, and long-term follow-up is the key to success.

\section{Additional Information \\ Disclosures}

Human subjects: Consent was obtained by all participants in this study. Animal subjects: All authors have confirmed that this study did not involve animal subjects or tissue. Conflicts of interest: In compliance with the ICMJE uniform disclosure form, all authors declare the following: Payment/services info: All authors have declared that no financial support was received from any organization for the submitted work. Financial relationships: All authors have declared that they have no financial relationships at present or within the previous three years with any organizations that might have an interest in the submitted work. Other relationships: All authors have declared that there are no other relationships or activities that could appear to have influenced the submitted work.

\section{References}

1. Madani H, Farrant J, Chhaya N, Anwar I, Marmery H, Platts A, Holloway B: Peripheral limb vascular malformations: an update of appropriate imaging and treatment options of a challenging condition. Br J Radiol. 2015, 88: 10.1259/bjr.20140406

2. Türkbey B, Peynircioğlu B, Arat A, et al.: Percutaneous management of peripheral vascular malformations: a single center experience. Diagn Interv Radiol. 2011, 11:363-367. 10.4261/1305-3825.DIR.3808-10.0

3. Tiwari R, Singh VK: Arterio venous malformation of the face: surgical treatment . J Maxillofac Oral Surg. 2015, 14:25-31. 10.1007/s12663-011-0270-5

4. Kramer U, Ernemann U, Fenchel M, Seeger A, Laub G, Claussen CD, Miller S: Pretreatment evaluation of peripheral vascular malformations using low-dose contrast-enhanced timeresolved 3D MR angiography: initial results in 22 patients. AJR Am J Roentgenol. 2011, 196:702-711. 10.2214/AJR.10.5092

5. Weiss RA, Sadick NS, Goldman MP, Weiss MA: Post-sclerotherapy compression: controlled comparative study of duration of compression and its effects on clinical outcome. Dermatol Surg. 1999, 25:105-108.

6. Ali S, Weiss CR, Sinha A, Eng J, Mitchell SE: The treatment of venous malformations with percutaneous sclerotherapy at a single academic medical center. Phlebology. 2016, 31:603609. 10.1177/0268355516633380

7. Delgado J, Bedoya MA, Gaballah M, Low DW, Cahill AM: Percutaneous sclerotherapy of foot venous malformations: evaluation of clinical response. Clin Radiol. 2014, 69:931-938. 10.1016/j.crad.2014.04.014

8. Guevara CJ, Gonzalez-Araiza G, Kim SK, Sheybani E, Darcy MD: Sclerotherapy of diffuse and infiltrative venous malformations of the hand and distal forearm. Cardiovasc Intervent Radiol. 2016, 39:705-710. 10.1007/s00270-015-1277-y

9. Tan KT, Kirby J, Rajan DK, Hayeems E, Beecroft JR, Simons ME: Percutaneous sodium tetradecyl sulfate sclerotherapy for peripheral venous vascular malformations: a single-center experience. J Vasc Interv Radiol. 2007, 31:343-351. 10.1016/j.jvir.2006.12.735

10. Castrén E, Aronniemi J, Klockars T, et al.: Complications of sclerotherapy for 75 head and neck venous malformations. Eur Arch Otorhinolaryngol. 2016, 273:1027-1036. 10.1007/s00405-015-3577-x

11. Burrows PE: Endovascular treatment of slow-flow vascular malformations. Tech Vasc Interv 


\section{Cureus}

Radiol. 2013, 16:12-21. 10.1053/j.tvir.2013.01.003 